\title{
An Assessment of the Performance of State Institutions in Environmental Protection in Taraba State, Nigeria
}

\author{
M. Bashir Babanyaya, E. D. Oruonye, and Y. M. Ahmed
}

\section{ABSTRACT}

This study examined the performance of State institutions in environmental protection in Taraba State with a view to ascertaining their capacity for environmental protection or otherwise and the challenges undermining their efforts. The study is anchored on the theory of Environmentally Responsible Behaviour (ERB). The study adopted survey research design using field observation and interview schedule. Yearly allocations to the two institutions were compiled from the yearly budget documents of the state. The study findings reveal that the state generate the highest revenue of $\$ 2$ billion in 2017 which is about $25 \%$ and $\$ 1$ billion in $2018,15.17 \%$ of the IGR. These were the pick period of the trade in African Rosewood logs in the state. The huge revenue gave legitimacy to the logging activities and explains why the activity persisted despite the existing forest regulations and efforts to stop it. Despite the huge revenue, findings revealed that it was only in the years 2000, 2013, and 2014 that the Ministry of Environment received up to $4 \%$ of the state budgetary allocation. The lowest allocation was in $2002(0.12 \%), 2016(0.15 \%)$ and $2007(0.18 \%)$. Findings also reveal huge gap between the budgetary allocation and the actual amount released or expended in the sector. The low budgetary allocation reveals low level of attention paid to environmental issues over the years. The findings of the study reveal that it is only in the area of revenue generation that the state institutions performed relatively well. In terms of staffing, capacity building, infrastructures and equipment, improvement in environmental legislation and enforcement of environmental regulation, the state institutions did not fare well. Based on the findings, the study recommended more political commitment, increase funding, employment of more technically skilled staff and establishment of data bank for environmental inventories in the state.

Keywords: Environmental protection, Performance, Ministry of Environment, State institutions and TASEPA.

Published Online: November 22, 2021

ISSN: 2684-446X

DOI :10.24018/ejgeo.2021.2.6.206

M. Bashir Babanyaya

Federal University Wukari, Taraba State, Nigeria.

(e-mail: bashirbabanyaya@gmail.com)

E. D. Oruonye*

Taraba State University, Jalingo, Taraba State, Nigeria.

(e-mail: eoruonye@gmail.com)

Y. M. Ahmed

Taraba State University, Jalingo, Taraba State, Nigeria.

(e-mail: Yushau20032003@gmail.com)

*Corresponding Author

\section{INTRODUCTION}

Over the years, there has been increase in the impact of man on the environment as a result of anthropogenic activities such as farming, mining, exploitation of natural resources, and other developmental activities. Singh and Suresh [1] states that in recent decades, many environmental problems have increased as a result of human activities and unplanned management of technological development leading to interference in the ecosystems. These result in conflict between the need for conservation and preservation of ecosystem to protect the environment and the necessity of satisfying basic human needs by sacrificing the environment across the world. Various human activities have caused many undesirable effects to the environment which can be threatening to human health, economic, natural resources, and gene pool of ecosystems such as pollutions, greenhouse effect, global warming, and soil erosion.
It is the need to harmonize the impact of human developmental activities and environmental protection that led to the first conference on environment and development in Stockholm in 1972. The Stockholm declaration is regarded as the first international soft law for the protection of the environment [2]. The 1972 Stockholm conference generated a lot of ideological controversy between the developed countries and the less developed, poor countries. The developed countries believed that the greatest challenges confronting the earth were environmental degradation while the less developed countries argued that the worst pollution and biodegradation are ultimately caused by poverty and consequently, greater development leading to material prosperity would have a great beneficial effect that far outweighs any damage caused by resource use and pollution. This ideological controversy between environmental protection and economic development presented a formidable challenge to international environmental diplomacy [3]. The compromise that 
subsequently worked out held that economic development was not necessarily incompatible with environmental protection and that development could proceed provided it avoided damaging the environment [3]. Subsequent development led to the establishment of the World Commission on Environment and Development in 1983, whose report, our common future defined sustainable development as; 'development that meets the needs of the present without compromising the ability of future generations to meet their own needs'. The outcome of subsequent conferences led to the establishment of many conventions in which Nigeria is a signatory. In Nigeria, the environmental concern came in the wake of the Koko toxic waste incidence of 1988. Since then the federal government has established many institutions charged with responsibilities of protecting the environment and put in place many legislative frameworks to back up the institutions. These institutional and legislative frameworks are cascaded to the state and local government levels. In Taraba State, we have the Ministry of Environment and Taraba State Environmental Protection Agency (TASEPA) among others.

Since the creation of Taraba State on the $27^{\text {th }}$ August 1991, thirty years now, many developmental projects were planned, constructed, and implemented with little or no attention to environmental considerations. Consequently, natural and environmental resources degradation, pollution, and flooding remain major problems. Despite the existence of these institutions, the environment in Taraba State has not fared better as there is an incessant increase in environmental degradations such as deforestation, floods, soil erosion, loss of biodiversity, increased windstorm, proliferation of abandoned and unreclaim mine sites, increase logging of timber among others.

It is against this backdrop that this study examined the Performance of the State Institutions in Environmental Protection in Taraba State with a view to ascertaining their capacity for environmental protection or otherwise and the challenges undermining their efforts.

\section{THEORETICAL FRAMEWORK}

This study is anchored on the theory of Environmentally Responsible Behaviour (ERB). The ERB theory was proposed by Hungerford and Volk in 1990. Environmentally Responsible Behaviour (ERB) is a concept that describes any action, individual or group, directed toward remediation of environmental issues/problems" [4]. Environmentally responsible behaviour is regarded by Steg and Vlek [5] to be a reflection of human behaviour that harms the environment as little as possible or even benefits it.

Environmental concern reveals the degree to which people have knowledge of the existence of environmental problems and take deliberate measures to solve them and or express willingness to contribute personally to solving such problems [6]. This willingness has so much to do with certain form of motivation. The motivation to be environmentally responsible according to Musova et al [7] is closely connected to individual's personal commitment to environmental protection and actions taken at this individual level to improve environmental quality. ERB is made up of a combination of self interest and concern for other people, species, or ecosystems [8]. Janene [9] observed that this includes both general actions (talking with others about environmental issues; encouraging family and friends to behave in environmentally responsible ways) and specific actions (recycling; purchasing environmentally friendly and sustainable goods; conservation of energy by turning off lights and using alternate sources of energy, such as solar, hydro, or wind energy; and reduction in fossil fuel dependence by utilizing alternative means of transportation) $[10,11]$.

The theory of environmentally responsible behavior (ERB) is relevant to this study because ERB highlights how vital existing interactions between parameters influence a person's behavior rather than focusing on the singular impact of a single variable. In waste management processes, no single factor is responsible for current behaviors or sufficient to initiate behavior or cause behavioral change. For instance, people dump their waste materials in the middle of the streets of Jalingo town, despite regulations from waste management authorities prohibiting these acts. Many of these defaulters do so at odd hours (in the night) when law enforcement agencies are not around, while others are influenced to dump these waste materials as a result of seeing people doing it.

\section{DESCRIPTION OF STUDY AREA}

Taraba State is located between latitude $6^{0} 25^{\prime} \mathrm{N}$ and $9^{0} 30^{\prime} \mathrm{N}$ and between longitude $9^{0} 30^{\prime} \mathrm{E}$ and $11^{\circ} 45 \mathrm{E}$. It is bordered on the West by Nasarawa and Plateau States, to the North by Bauchi and Gombe States, and by Adamawa state to the Northeast. It also shares its South Western boundary with Benue State. Taraba State is bounded on the South and East by Republic of Cameroon (an international boundary). The state covers a land area of about $60,291 \mathrm{~km}^{2}$ [12].

Taraba State has tropical continental climate. It has a wet and dry season. The rainfall distribution pattern in the state shows a decrease from the South to the Northern part. Rainfall duration lasts between 260 days in the Southern part to 190 days in the Northern part. Rainfall amount varies from $1000 \mathrm{~mm}^{3}$ in the Northern to $2500 \mathrm{~mm}^{3}$ in the Southern part. The state experience high temperature all year round because of its latitudinal location also. The mean maximum temperature for most parts of the state is about $30^{\circ} \mathrm{C}$. The highest air temperature is normally experienced in March and April in the Northern part of the state and much earlier in the South [12].

The soil can be divided into four major types such as ferralsols, ferrisols, hydromorphic and alluvial soils. The vegetation of Taraba state can broadly be grouped under the guinea savanna vegetation. This guinea savanna vegetation can be further subdivided based on structural and floristic composition into; Wooded savanna in the Northern part, Mixes leguminous wooded savanna, Forest savanna mosaic to the South, Plateau grass savanna /Montane vegetation and Flood plain complexes/gallery forest [12].

Taraba state is underlain by Basement complex and sedimentary rocks, each occupying a very distinctive part of the state. The basement complex consists of granites (igneous) and metamorphic gneiss and schist rock. While 
the sedimentary rocks are found only along the valleys of River Benue and its major tributaries such as River Donga and Taraba [13].

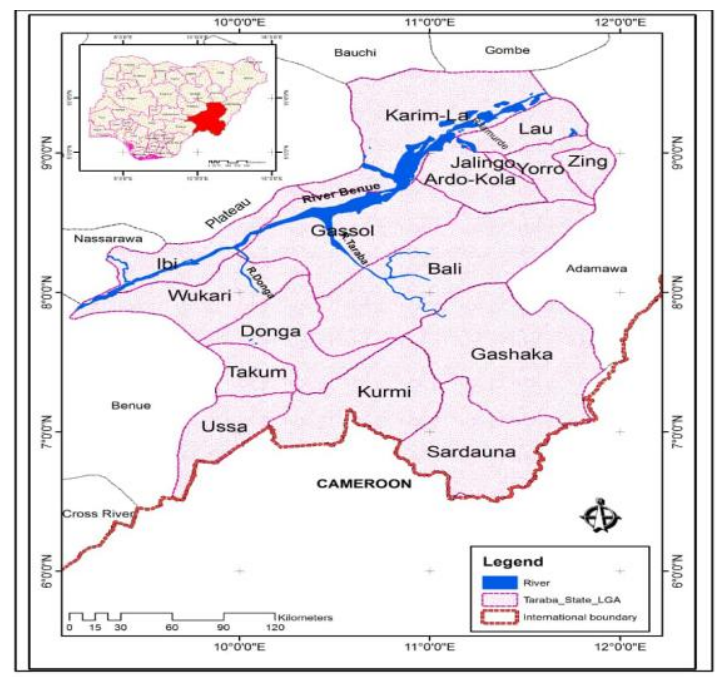

Fig. 1. Map of Taraba State.

The Mambilla plateau is an important watershed from which the major drainage systems in Taraba state take their source [13]. River Benue and its tributaries such as Rivers Donga, Ibi and Taraba are the major rivers that drain most part of the state to link up with the River Niger. The minor Rivers, such as the Lamurde, Kam, Kunini, Didango, Gashaka, Bali and Mayo Renewo Rivers form extensive flood plains in the central part of the state [12].

The population of Taraba state, according to the 2006 National Population Census, was 2,300,736. The state has a population growth rate of about $3.1 \%$ per annum. Based on this growth rate, the state population is projected to be $3,459,303$ in 2021. Taraba state is highly heterogeneous and multi-ethnic in nature with close to eighty indigenous ethnic groups speaking different languages [14]. Major ethnic groups include Fulani, Mumuye, Jukum, Jenjo, Kuteb, Chamba, and Etkwen (Itean), Kpan, Samba Daka, Tiv, Yendang, and Mambilla, each forming a mosaic in at least one local government area [14].

Farming is the major socio-economic activity in Taraba State. This is the reason why the State is considered as an agrarian state with $75 \%$ of the population engaging in agricultural activities. The State is endowed with vast arable land suitable for cultivation of variety of both food and cash crops.

\section{MATERIALS AND METHODS}

This study considers Taraba State Ministry of Environment and Taraba State Environmental Protection Agency (TASEPA) as the main focus. The study examines the mandate of these two State Institutions on environmental protection, their performance, and challenges undermining their efforts. The study examines the institutional capacity in terms of funding, adequate manpower, sufficient equipment, and operational logistics among others. Similarly, the study appraised the activities of the state institutions from the time of establishment to date (2000-2021).
The study adopted survey research design which involves the use of direct observation and measurements. Primary and secondary data were used. Primary data was generated from field observation and interviews of key informants. Secondary data was obtained from existing sources such as journals, books, newspapers, websites, publications, archival records of government ministries and departments. Oral interview was held with top officials of the Ministry and agency.

\section{A. Assessment of Performance of State Institutions}

Assessing an institution's performance requires comparing the state of the environment in the presence of an environmental institution to the best estimate of what that state would have been in the absence of the institution [15]. Assessing the performance of institutions has always proven difficult because of the inability to have empirical standards that is generally accepted among scholars. So many past studies have used different performance standards for assessing the performance of organizations. In this study, the state institutions are the main independent variable of interest, while the performance of the institutions is the dependent variable. The aspirations of the government in establishing the institutions, the expectations of the citizens, other interested parties, and stakeholders are considered in assessment of the performance of the institutions. Thus, performance assessment seeks to identify how much the state institutions have contributed to whatever progress was made towards environmental protection in the state [15]. The study, therefore, adopts the following key performance indicators to assess the performance of the state institutions in environmental protection in the state:

i. Revenue generation.

ii. Capacity building - in terms of training of workers.

iii.Staffing of the organizations - number of staffs in the agency.

iv. Adequacy of infrastructures and equipment.

v. Project execution

vi. Improvement in Environmental Legislation.

vii. Enforcement of Environmental Regulations.

viii. Other achievements.

The data collected using questionnaires were analyzed using descriptive statistics. This was done with Statistical Package for Social Sciences (SPSS) package. The results were presented using frequency tables and percentages. Content analysis method was used in the analysis of data collected through interviews.

\section{RESUlt OF THE FINDINGS}

\section{A. Performance of the State Institutions in Environmental Protection}

The State institutions were established with specific mandate to achieve in respect of environmental protection. This section focuses on the extent to which these state institutions have achieved these mandates using the performance indicators earlier enumerated as presented below; 


\section{B. Revenue Generation}

The state institutions apart from making policies and legislations to protect the environment also generate revenue for the government. The Ministry of environment generates revenue through the sales of tree seedlings, sales of wood and poles, trophy dealer license, and exploitation of mineral resources. The Taraba State Environmental Protection Agency on the other hand generate revenue through registration of facilities, registration of environmental consultants, renewal of registration, EIA/ EA registration, verification of EIA/ EA reports, conduct of environmental audit, issuance of a certificate of standard compliance, issuance of permits and license and fines/penalties for standard violations. The breakdown of the revenue generated by these two institutions is presented in Tables I and II.

\begin{tabular}{|c|c|c|c|c|c|}
\hline Year & $\begin{array}{c}\text { Sales of Tree } \\
\text { Seedlings }\end{array}$ & $\begin{array}{l}\text { Pass Hammer / } \\
\text { trophy license }\end{array}$ & $\begin{array}{c}\text { Sales of Woods and } \\
\text { Poles }\end{array}$ & $\begin{array}{l}\text { Total Revenue of } \\
\text { Ministry of Envir }\end{array}$ & $\begin{array}{c}\text { Revenue Estimate of } \\
\text { TASEPA }\end{array}$ \\
\hline 2005 & $\$ 1,000,000.00$ & $\$ 500,000.00$ & $\$ 1,500,000.00$ & $\$ 3,000,000.00$ & NA \\
\hline 2006 & $\$ 2,000,000.00$ & $\$ 500,000.00$ & $\$ 3,000,000.00$ & $\$ 5,500,000.00$ & NA \\
\hline 2007 & NA & NA & NA & $\$ 1,100,000.00$ & NA \\
\hline 2008 & NA & NA & NA & $\$ 1,730,000.00$ & NA \\
\hline 2009 & $\$ 1,000,000.00$ & $¥ 6,000,000.00$ & $\$ 3,000,000.00$ & $\$ 11,990,000.00$ & NA \\
\hline 2010 & $\$ 1,500,000.00$ & $\mathrm{~A} 1,500,000.00$ & $\$ 5,180,000.00$ & $\$ 10,760,000.00$ & NA \\
\hline 2011 & NA & $\$ 14,810,000.00$ & $\$ 1,500,000.00$ & $¥ 15,465.300 .00$ & NA \\
\hline 2012 & NA & A8,180.000.00 & \#1,500,000.00 & $\aleph 19,100,000.00$ & NA \\
\hline 2013 & NA & $\$ 6,000.000 .00$ & $\$ 12,000.000 .00$ & $\$ 19,100,000.00$ & NA \\
\hline 2014 & NA & NA & $\$ 12,000.000 .00$ & $\$ 10,943,136.00$ & NA \\
\hline 2015 & NA & NA & $\$ 13,200.000 .00$ & N12,037,449.60 & NA \\
\hline 2016 & Solid Minerals & $\$ 33,000.00$ & $\$ 540,000,000.00$ & $\$ 540,033,000.00$ & NA \\
\hline 2017 & $\mathrm{~A} 1,600,000,000.00$ & $\mathrm{~N} 120,000.00$ & $\mathrm{~N} 400,120,000.00$ & $\approx 2,000,240,000.00$ & $¥ 42,100,000.00$ \\
\hline 2018 & $\$ 500,000,000.00$ & $\$ 132,000.00$ & $\$ 600,090,000.00$ & $\$ 1,100,222,000.00$ & $\$ 44,890,000.00$ \\
\hline 2019 & $\$ 550,000,000.00$ & $\$ 145,000.00$ & N660,099,000.00 & $\$ 660,244,200.00$ & $¥ 49,379,000.00$ \\
\hline 2020 & $\$ 605,000,000.00$ & $\$ 159,720.00$ & $\mathrm{~N} 726,108,900.00$ & N726,268,620.00 & $\$ 54,316,900.00$ \\
\hline
\end{tabular}

Source: Compiled from Taraba State Planning Commission Jalingo.

NA: Not Available.

TABLE II: ESTIMATED REVENUES FROM MINISTRY OF ENVIRONMENTAL FROM 2005-2021

\begin{tabular}{|c|c|c|c|c|}
\hline $\mathrm{S} / \mathrm{N}$ & Year & $\begin{array}{l}\text { Taraba State Internally } \\
\text { Generated Revenue }\end{array}$ & $\begin{array}{c}\text { Revenue Estimate of } \\
\text { Ministry of Environment }\end{array}$ & $\begin{array}{l}\text { Percentage of } \\
\text { IGR }(\%)\end{array}$ \\
\hline 6 & 2005 & $\mathrm{~N} 793,466,240.00$ & $¥ 3,550,000.00$ & 0.45 \\
\hline 7 & 2006 & $\$ 2,189,300,574.00$ & $\$ 5,550,000.00$ & 0.25 \\
\hline 8 & 2007 & $\mathrm{~N} 2,240,117,675.00$ & $\$ 5,550,000.00$ & 0.25 \\
\hline 9 & 2008 & $\$ 2,069,369,535.00$ & $11,730,000.00$ & 0.08 \\
\hline 10 & 2009 & $\$ 3,500,000,000.00$ & $¥ 11,990,000.00$ & 0.34 \\
\hline 11 & 2010 & $\$ 3,323,509,720.00$ & $\$ 10,760,000.00$ & 0.32 \\
\hline 12 & 2011 & $¥ 4,703,408,321.00$ & $\$ 15,465,300.00$ & 0.33 \\
\hline 13 & 2012 & $\$ 6,083,306,923.00$ & $¥ 19,100,000.00$ & 0.31 \\
\hline 14 & 2013 & $\$ 8,833,710,016.00$ & $\$ 19,100,000.00$ & 0.22 \\
\hline 15 & 2014 & $\$ 7,049,329,685.00$ & $\$ 10,943,136.00$ & 0.16 \\
\hline 16 & 2015 & $\$ 7,754,262,653.00$ & $\mathrm{~N} 12,037,449.60$ & 0.16 \\
\hline 17 & 2016 & $\$ 8,529,688,918.00$ & $¥ 540,033,000.00$ & 6.33 \\
\hline 18 & 2017 & $\$ 8,006,469,163.00$ & $\approx 2,000,240,000.00$ & 24.98 \\
\hline 19 & 2018 & N7,004,696,079.30 & $\$ 1,100,222,000.00$ & 15.71 \\
\hline 20 & 2019 & $¥ 6,431,595,324.00$ & 660,244,200.00 & 10.27 \\
\hline 21 & 2020 & $\mathrm{~N} 7,074,754,856.00$ & $\mathrm{~N} 726,268,620.00$ & 10.27 \\
\hline
\end{tabular}

Source: Compiled from Taraba State Planning Commission Jalingo.

NA: Not Available.

The yearly budget of the State and allocations to the two institutions were compiled from the yearly budget documents of the Taraba State Planning Commission Jalingo. Findings from the study reveals that the state generate the highest revenue of 2 billion in 2017 which is about $25 \%$ (Table II) of the total estimated internal generated revenue (IGR) for that year and $\mathrm{N} 1$ billion in $2018,15.17 \%$ of the IGR. These were the pick period of the trade-in African Rosewood logs in the state. This revenue collected by the government gave legitimacy to the logging activities and explains why the activity persisted despite the existing forest regulations and efforts to stop it [16]. Despite the huge amount of money generated from the logging activities, there were no adequate statistics of the volume of logs exploited and the amount generated. The logging activities were shrouded in lots of secrecy, corruption, and connivance with government officials.

\section{Capacity Building}

This is a set of activities aimed at developing individuals and institutions' capacity to carry out effectively goal oriented activities to achieve its mandates. Capacity building also has to do with developing expertise in specific area of interest within the operational mandate of an organization through periodic training and workshops. These include expertise in scientific, technical, economic, legal, social science and their integration in design and implementation in policy decisions. There are many areas of capacity needs in the state institutions that are yet to be addressed such as abilities to assess and compare various potential solutions and strategies to manage environmental problems. This includes capacity for research and analysis such as the capacity to recognize, analyze and define environmental problems and their causes as well as the management 
process. Despite the fact that provisions are made in the yearly budget for capacity building in the state institutions, this is hardly achieved most often because of poor funding of the sector.

\section{Staffing of the Organizations}

Environmental protection requires a number of qualified and well-trained staff to carry out the very wide task of environmental protection, monitoring, enforcement of regulation, and patrolling of various forest and game reserves. Findings of the study revealed that since its establishment, no employment or engagement of new staff was made in the sector. At the time of the creation of Taraba State in 1991, the Ministry of Environment and TASEPA has 350 staff. Presently TASEPA has 28 staff while the Ministry of Environment has 144 staff. Both the Ministry of Environment and TASEPA have lost 178 staff to retirement, death, and transfer without replacement. Thus, the state institutions have performed very poor in this aspect.

\section{E. Adequacy of Infrastructures and Equipment}

Effective environmental protection requires good infrastructure and state of the art equipment for setting and measuring standards for various environmental parameters. This infrastructure includes environmental laboratory. TASEPA has one environmental laboratory that was vandalized during the end SARS protest in Nigeria on $20^{\text {th }}$ October 2020 (Plate 1).
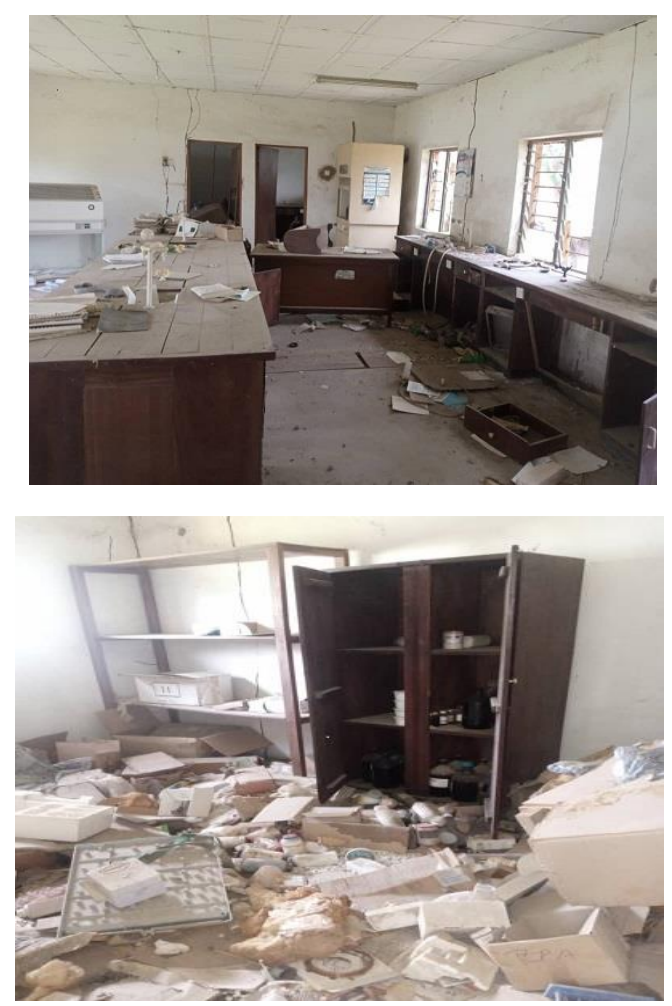

Plate 1. Vandalized Environmental laboratory.

\section{F. Project Execution}

Most of the project execution carried out by the agency was mainly the establishment of the environmental protection laboratory which was now destroyed. Other projects include tree planting and distribution of tree seedlings in collaboration with some non-governmental organizations and institutions in the state.

\section{G. Improvement in Environmental Legislation in the State}

Taraba state adopted the Forestry Law 1963 and amended it as 'Taraba State Forestry Law (Amendment) Edict 1997' which was later amended to 'Taraba State Forestry Law (Amendment) 2010'. The purpose of the Edict was to amend the Forest Law (Cap 44 Laws of Northern Nigeria 1963) to make provisions vesting the control, preservation, and management of forests resources solely in the State Government [17]. Although there was existing forestry regulation banning the exploitation and export of timber (including African Rosewood), the State government made effort to reinforce the regulation between 2007 and 2009. The Taraba state (Control of Chainsaws) Law 2003 provides that "No person shall use any chainsaw for felling any tree in the state unless he shall first have applied and obtained permission from the Ministry of Environment by way of license. Such persons were also expected to establish sawmill for the industrial processing of the forestry resources [18]. Violators of this law are liable upon conviction to a fine of $\$ 50,000$ or a jail term of five years.

Forest reserves have been established in various parts of the state, either for timber development or fuelwood exploitation. There are 49 forest reserves and 98 plantations in Taraba state (Taraba state tourist guide). There are 27 gazetted and 12 non-gazetted (proposed) forest reserves in Taraba State. This not withstanding, some of the fines and penalties of environmental regulation offenders are already obsolete and overtaking by the inflationary trends in the country. There is a need to review the existing laws and regulations and enact new ones to meet up with increasing environmental challenges in the state.

\section{H. Enforcement of Environmental Regulations}

Available records show that from the time of the state creation to date, the department has only been able to make about 287 prosecutions of forestry related offences. So many seizures of timber sawing machines were made but statistics of a number of such seizures are not available [18]. According to the State Director of Forestry, virtually all the forest reserves in the state have been encroached upon through settlement occupation, grazing and farming activities. This clearly demonstrated the poor capacity of the state institutions to effectively enforce environmental protection regulations in the state.

\section{Other Achievement}

The State institutions are supposed to carry out other activities such as establishing natural resource conservation projects, expansion of grazing and forest reserves, establishment of nursery for seedlings among others. Although the officials of the two state institutions claimed to have established many tree planting sites in the State, findings of the study revealed that instead of expanding the existing grazing and forest reserves, the state actually lose some of the grazing and forest reserves to encroachment by both crop farmers and settlement expansion. The Global Biodiversity Outlook [19] report reveals that the expansion of protected areas is one of the positive indicators of environmental performance. 
The Ministry of Environment identified several solid minerals in the different parts of the State such as Gold, Gemstone, Sapphire, industrial minerals (Barite), metallic mineral (Columbite), etc. Over 50 known occurring mineral types have been located and sampled. The Ministry also incorporated and registered Taraba Solid Minerals Development Company Limited (TSMD) and undertook a satellite mineral survey of four block areas within the State of hydrocarbon and other minerals within the Benue Trough in 2012 .

The Taraba State Solid Mineral Development Company Limited (TSMDC) acquired from the Federal Ministry of Solid Minerals Development title deeds i.e. Certificate of Ownership (C of $\mathrm{O}$ ) for over 16 sites for different minerals. The Ministry attended both domestic and international trade fairs where the various mineral potentials of the State were exhibited to the outside world.

\section{Challenges Undermining THE PERFORMANCE OF STATE INSTITUTIONS}

\section{A. Funding}

The funding of the activities of an organization or agency is a clear demonstration of political will towards a course of action. The budgetary allocation of the state to the Ministry of environment and its institution, TASEPA as well as the recurrent and capital expenditure between 2000 to 2021 are presented in Table III. The Table reveals that despite the revenue generation of the state institutions on environmental protection, not much has been invested in the sector. There is a huge gap between the budgetary allocation and the actual amount released or expended in the sector. For example, in 2016, $\$ 1,890,587,100.00$ was actually approved for recurrent expenditure for the Ministry of Environment, but the actual expenditure was $183,770,015.00$ [20]. In 2016 also, $\$ 27,428,140.00$ was actually approved for recurrent expenditure for the Taraba State Environmental Protection Agency, but the actual expenditure was $¥ 13,734,265.00$ [21].

The information in Table III revealed that it was only in the years 2000, 2013, and 2014 that the Ministry received up to $4 \%$ of the state budgetary allocation. The lowest allocation was in $2002(0.12 \%), 2016(0.15 \%)$ and 2007 $(0.18 \%)$. The picture above is not far from what is obtainable at the Federal level. This goes to show the low level of attention paid to environmental issues over the years.

TABLE III: TARABA StATE BUDGET ALlOCATION TO Ministry OF ENVIRONMENT From 2000-2021

\begin{tabular}{|c|c|c|c|c|c|}
\hline Year & $\begin{array}{c}\text { Taraba state budget } \\
\text { allocation }\end{array}$ & $\begin{array}{c}\text { Budget allocation to } \\
\text { Ministry of } \\
\text { Environment }\end{array}$ & $\begin{array}{l}\text { Percentage of } \\
\text { budget }(\%)\end{array}$ & $\begin{array}{c}\text { Approved } \\
\text { Recurrent } \\
\text { Expenditure }\end{array}$ & $\begin{array}{c}\text { Approved Capital } \\
\text { Expenditure for Envir. } \\
\text { Protectn }\end{array}$ \\
\hline 2000 & $1,349,984,295$ & No Allocation & - & NA & NA \\
\hline 2001 & $2,423,289,128$ & $115,885,015$ & 4.78 & NA & NA \\
\hline 2002 & $6,228,281,297$ & $79,023,860$ & 0.13 & NA & NA \\
\hline 2003 & $12,129,963,189$ & $111,600,000$ & 0.92 & NA & NA \\
\hline 2004 & $21,593,421,875$ & $601,600,000$ & 2.78 & NA & NA \\
\hline 2005 & $24,129,234,120$ & $603,600,000$ & 0.24 & NA & NA \\
\hline 2006 & $24,231,108,740$ & $86,354,660$ & 0.35 & $¥ 6,000,000.00$ & NA \\
\hline 2007 & $31,934,660,280$ & $59,702,140$ & 0.18 & $¥ 6,000,000.00$ & NA \\
\hline 2008 & $37,560,261,475$ & $569,951,605$ & 1.51 & $\$ 10,000,000.00$ & NA \\
\hline 2009 & $¥ 48,968,486,645.00$ & $282,935,345$ & 0.62 & NA & $\$ 50,000,000.00$ \\
\hline 2010 & $¥ 64,144,351,808.00$ & N1,204,057,530.00 & 1.88 & $\approx 205,057,530.00$ & N999,000,000.00 \\
\hline 2011 & $70,298,282,182.00$ & $298,709,585$ & 0.42 & NA & NA \\
\hline 2012 & $\mathrm{~N} 73,852,442,531.00$ & NA & NA & $\mathrm{N} 15,000.000 .00$ & N115,000.000.00 \\
\hline 2013 & $¥ 73,415,972,736.00$ & $¥ 60,000,000.00$ & 0.08 & \#15,000.000.00 & N124,500.000.00 \\
\hline 2014 & $¥ 83,355,337,529.00$ & 丹1,005,113,859.00 & 1.21 & NA & N277,166,330.00 \\
\hline 2015 & 丹97,319,103,027.00 & N950,113,859.00 & 0.98 & NA & N870,124,699.00 \\
\hline 2016 & $¥ 100,785,000,000.00$ & N1,111,083,394.00 & 1.10 & $¥ 1,890,587,100.00$ & N948,435,921.00 \\
\hline 2017 & N110,168,983,942.00 & NA & NA & 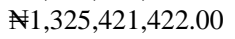 & $\mathrm{N} 1,033,795,154.88$ \\
\hline 2018 & $146,073,726,882.10$ & $34,352,440$ & 1.32 & $¥ 411,709,349.98$ & $\approx 289,500,000.00$ \\
\hline 2019 & $146,073,726,882.10$ & $1,780,735,468$ & 1.2 & $\mathrm{~N} 312,013,191.48$ & $\approx 315,555,000.00$ \\
\hline 2020 & $176,616,318,475.00$ & $654,500,000.00$ & 0.52 & NA & $¥ 949,009,950.00$ \\
\hline 2021 & $139,460,435,961.80$ & $2,119,9240,071$ & 1.52 & NA & NA \\
\hline
\end{tabular}

Source: Compiled from Taraba State Planning Commission Jalingo.

NA: Not Available.

\section{B. Weak Environmental Governance}

This manifest in so many dimensions such as the lack of clearly defined environmental policies, obsolete legislation, and lack of adequate enforcement of environmental policies and laws in the State. This also is a result of lack of political will on the part of the government. These weaknesses are difficult to address politically since well-connected interest groups tend to benefit from the status quo and resist change [16]. Colchester [21] argues that many existing forest laws actually harm the poor and that current forest law enforcement and governance efforts often focus too heavily on enforcement of legislation and not enough on getting the laws correct. This is further worsened by Government preference and emphasis on revenue generation as against biodiversity conservation and environmental protection.

\section{Weak Institutional Structures \\ D. Inadequate manpower}

The Ministry of Environment and TASEPA has 350 staff altogether as at the time of creation of the state in 1991. Presently, the total number of staff has reduced to 144 staff. The state institutions have lost about 178 staff in the past 3 decades. Many staff has retired and others died but there was no replacement. This clearly shows that the state 
institutions are grossly understaffed. This by implication has a tendency to undermine the performance of the institutions towards environmental protection in the state.

\section{E. Lack of capacity}

This results from the inability of the state institutions to monitor and enforce environmental regulations especially forestry legislations in the state. There has been persistent encroachment into the forest and game reserves, illegal logging, a high rate of agricultural activities in the reserved area, and unsustainable exploitation of forest resources. Despite the setting up of a task force (special committee) by the Ministry of Environment to curb deforestation in the state, illegal logging of trees has continued to thrive in different parts of the state. The forest resources of the state are fast disappearing as a result of high exploitation [16]. The state institutions suffer from a lack of effective supervision, coordination, and enforcement of forest legislation. In the past forest guards and rangers were employed and given uniform, rain boot or footwear and guns to patrol the forest reserve areas, monitor and protect the forest and wildlife resources. But today, there has been no employment in the forest sector in the state for the past 3 decades which was worsened by poor funding of the sector.

\section{F. Lack of or dilapidated officel accommodation}

The state institutions of environmental protection lacked a good and well-furnished office complex. The environmental laboratory of the state environmental agency was vandalized during the end SARS demonstration that took place across the country on $20^{\text {th }}$ October 2021. This has further demotivated the staff of the institutions, thereby resulting in poor performance.

\section{G. Corruption}

Corruption and conspiracy of officials of state institutions and environmental regulation offenders such as the case of forestry officers, village heads, and chiefs with merchant timber loggers. A study by Ahmed and Oruonye [16] revealed that environmental monitoring activities in the state have been plagued with complicity by some corrupt forestry officials. This has greatly undermined efforts at enforcing environmental protection regulations in the state.

\section{H. Lack of database}

There is no database on environmental resources and environmental problems in the state. This makes it difficult to ascertain the areal extent of natural resources e.g. forest reserves and extent of encroachment by both the farmers and cattle grazers, mineral resources, and reserves in the state. Baseline data for effective monitoring of environmental changes are completely non-existent, thereby making environmental impact assessment difficult.

\section{Lack of cooperation by stakeholders}

Lack of cooperation by stakeholders such as the traditional rulers, timber dealers, and local communities.

\section{J. Low public environmental awareness}

There is a general low public environmental awareness of the existence of most environmental laws, standards and regulations especially on forest reserves, grazing reserves, game reserves, and related legislation in the state as a result of poor enlightenment campaign.

\section{K. Lack of technical skills}

The state institutions lack the technical skills required to manage environmental problems and natural resources effectively in the state.

\section{CONCLUSION}

This study has assessed the performance of state institutions in environmental protection in Taraba State, Nigeria. Based on the criteria developed for assessing the performance of the state institutions, the study findings reveal that it is only in the area of revenue generation that the state institutions performed relatively well. In terms of staffing, capacity building, infrastructures and equipment, improvement in environmental legislation, and enforcement of environmental regulation, the state institutions did not fare well. Some of the challenges undermining the capacity of the state institutions include poor funding, weak institutional structures, inadequate manpower, lack of capacity, lack of or dilapidated office/accommodation, corruption and conspiracy of officials, and lack of a database.

\section{RECOMMENDATIONS}

Based on the findings of the study, the following recommendations were made;

i. There is a need for more political commitment to the issues of environmental protection in the state. This can be achieved through increased funding by way of increased budgetary allocations to the institutions.

ii. The State government should employ more qualified personnel in various aspects of environmental protection. There is a need to fill in the gaps in the workforce of the institutions.

iii. There is a need to rehabilitate the existing environmental protection laboratories in the state and as well establish more state of the art laboratories. Building a new office complex for the state institutions on environmental protection will go a long way in motivating them to put more into their work.

iv. The State government should pay more attention to the issue of capacity development so as to meet up with the changing nature of environmental problems. More staff of the state institutions need to be trained periodically on new modern methods of managing environmental problems. This will help to increase the technical skills of the staff.

v. There is a need to establish a data bank that will contain inventories on environmental resources in the state.

\section{ACKNOWLEDGMENT}

The authors are grateful to the staff of the Ministry of Environment Jalingo and Taraba State Environmental Protection Agency (TASEPA) for providing useful information that helps to the success of this study. The 
authors also appreciate the positive criticism of staff of the Department of Geography, Taraba State University Jalingo during the seminar presentation.

\section{COMPETING INTERESTS}

Authors have declared that no competing interests exist in this study.

\section{REFERENCES}

[1] Singh RB, Suresh P, Environmental Law in India. New Delhi: Misra Publications, 2005.

[2] Onifade TT. Legal and Institutional Framework for Promoting Environmental Sustainability in Nigeria Through Renewable Energy: Possible Lessons from Brazil, China and India. A Dissertation Submitted to the Faculty of Law, University of Ibadan, in Partial Fulfillment of the requirements for the award of the degree of Master of Laws (LL.M.) of the University of Ibadan, Nigeria, 2015.

[3] Guruswamy LD. International Environmental Law and World Order p. 34, 2007.

[4] Sivek DJ, Hungerford H. Predictors of responsible behavior in three Wisconsin conservation organizations. The Journal of Environmental Education, 1989; 17(2), 31-40.

[5] Steg L, Vlek C, Encouraging pro-environmental behaviour: an integrative review and research agenda. Journal of Environmental Psychology, 2009; 29(3), 309-317.

[6] Dunlap R, Jones R. Environmental Concern: Conceptual and Measurement Issues. In Dunlap and Michelson (Ed), Handbook of Environmental Sociology, 482-542. London, Greenwood Press, 2002.

[7] Musova Z, Musa H, Matiova V. Environmentally responsible behaviour of consumers: Evidence from Slovakia. Economics and Sociology, 2021; 14(1), 178-198. doi:10.14254/2071-789X.2021/14$1 / 12$

[8] Bamberg S, Moser G. Twenty years after Hines, Hungerford, and Tomera: A new meta-analysis and psycho-social determinants of proenvironmental behavior. Journal of Environmental Psychology, 2007; $27,14-25$

[9] Janene MG. Environmentally Responsible Behavior and the Application of Leave No Trace Beyond the Backcountry. A Thesis Submitted to the Faculty of the Gladys W. and David H. Patton College of Education and Human Services of Ohio University in partial fulfillment of the requirements for the degree Master of Science, 2011.

[10] Cottrell SP. Influence of socio demographics and environmental attitudes on general responsible environmental behavior among recreational boaters. Environment \& Behavior, 2003; 35(3), 347.

[11] Thogersen J, Norms for environmentally responsible behaviour: An extended taxonomy. Journal of Environmental Psychology, 2006; 26(4), 247-261.

[12] Oruonye ED, Abbas B, The Geography of Taraba State Nigeria. LAP LAMBERT Academic Publishing GnBH \& Co.KG and licensors, 2011.

[13] Bashir A. "Taraba State" In Mamman AB, Oyebanji JO, Petter SW (Eds.) Nigeria-A People United, A Future Assured (State Survey). Vol. 2 Millennium Edition. Federal Ministry of Information, Abuja, Nigeria, 2000 .

[14] Bashir A. "Taraba State" In Udo RK, Mamman AB, (Eds.) NigeriaGiant in the Tropics (State Survey). Vol. 2. Heritage Edition, Gabumo Publishing Co Ltd. Lagos, Nigeria. pp. 451-463, 1993.

[15] Mitchell RB. Evaluating the Performance of Environmental Institutions: What to Evaluate and How to Evaluate It?. In Institutions and Environmental Change: Principal Findings, Applications, and Research Frontiers. Editors: Oran R. Young, Leslie A. King, and Heike Schroeder. MIT Press, 2008, 79-114.

[16] Ahmed YM, Oruonye ED, Ayuba HK. Socio-economic Impact of Commercial Production of Rosewood (Pterocarpus erinaceus) in Taraba State, Nigeria. Journal of Agriculture and Ecology Research International. 2016b; 7(3); 1-9. www.sciencedomain.org.

[17] Ahmed YM, Oruonye ED. Challenges of Enforcement of Forestry Legislation in Taraba State, Nigeria. International Journal of Geography and Geology, 2017; 6(3); 48-57. www.pakinsight.com

[18] Ahmed YM, Oruonye ED, Tukura E. Dynamics of Rosewood (Pterocarpus erinaceus), Exploitation in Savanna lands of Taraba State Nigeria. Sky Journal of Soil Science and Environmental Management, 2016a ; 5(2); 44-51. www.skyjournals.org/SJSSEM
[19] Global Biodiversity Outlook, Convention on Biological Diversity, 2010. www.cbd.int/gbo5.

[20] Taraba State Government (TSG) 2017-2019 Multi Year Estimates. Taraba State, 2017.

[21] Colchester M, Justice in the forest: Rural livelihoods and forest law enforcement. CIFOR Forest Perspectives 3. Bogor, Indonesia: CIFOR, 2006.

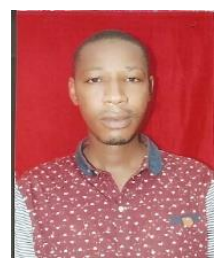

Bashir Mohammed Babanyaya was Born on $5^{\text {th }}$ May, 1989 in Jalingo Local Government area of Taraba State. After elementary schooling in Centre for Excellence Primary school (1994-2000) and secondary education at Kanta College Argungu, Kebbi State (2000-2006), he went to Taraba State College of Education Jalingo, where he obtained a National Certificate in Education (NCE) 2006-2009. Then from 2010-2014, he studied at the University of Maiduguri Borno State, where he obtained a bachelor degree (B.Sc.) in Geography Education, after which he served as a youth corps member with the Department of Geography, Taraba State University, Jalingo between 2014-2015. Bashir Babanyaya then proceeded to Taraba State University, Jalingo to pursue a higher degree in Environmental Resource Management (M.Sc. in view). He is currently a Graduate Assistant at Federal University, Wukari, Taraba State.

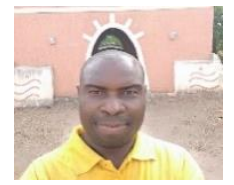

Emeka Daniel Oruonye $(\mathrm{PhD})$ is a Professor of Environmental Science in the Department of Geography, Taraba State University Jalingo. He obtained his B.Sc., M.Sc., and Doctorate degree from the University of Maiduguri. He was the author of the books Geographical Aspects of Yobe State, Climate Change Perception Among Rural Farmers in Taraba State Nigeria and coauthor of History, Culture, and Tourism Potentials of Yobe State, Socioeconomic and Ecological Impact of Resettlement Scheme along the Lake Chad Region of Nigeria, and the Geography of Taraba State Nigeria. He has also published many journal articles in local and international journals $\mathrm{He}$ is editor in chief of Jalingo Journal of social and management sciences and editorial board member of many local and international journals. He is a member of many professional bodies including the Association of Nigerian Geographers (ANG), Association of American Geographers (AAG), and African Forest Forum (AFF). He is a consultant in environmental management. He is an environmental consultant.

Dr. Ahmed Yushau Mohammed, (The Sardauna of Wurojam, a titled Chief of Wurojam District in Gassol Local Government Area) attended Bali central primary school from 1974-1979. He attended GSS Wukari and later Government Science Secondary School Donga. He obtained his National Diploma in General forestry and environment in 1986. He further went to Forestry Research Institute of Nigeria Federal College of Forestry (FRIN) Jos. He studied arid zone and savannah forestry with specialization in Desert Technology. He went to University of Nigeria Nsukka for his post graduate Diploma from 1990-1991. He obtained his Master's Degree (M.Sc.) in 1994 and Ph.D at University of Jos in 2014.

He worked as a civil servant in Bali LGA of former Gongola state as Forestry superintendent from 1986-1987 to Higher Forestry superintenden and Principal Forestry Officer in 1996 where he transferred his service to Federal Government in 1996. He rose to Principal Scientific Officer in 1999, Assistant Chief Scientific Officer and Chief Scientific in 2002 and 2004 respectively. Between 2004 to 2010 he was promoted to Assistant Director and Deputy Director of the Mines Environmental Compliance Department. He joined Taraba state University in 2014. He is a member of so many professional bodies and has a number of publications in peer reviewed journals. He is presently the Head, Department of Geography, Taraba State University, Jalingo. 